Article

\title{
Food Waste Materials as Low-Cost Adsorbents for the Removal of Volatile Organic Compounds from Wastewater
}

\author{
Maria Agostina Frezzini ${ }^{D}$, Lorenzo Massimi ${ }^{\circledR}$, Maria Luisa Astolfi, Silvia Canepari and \\ Antonella Giuliano* \\ Department of Chemistry, Sapienza University of Rome, Piazzale Aldo Moro, 5, 00185 Rome, Italy; \\ mariaagostina.frezzini@uniroma1.it (M.A.F.); 1.massimi@uniroma1.it (L.M.); \\ marialuisa.astolfi@uniroma1.it (M.L.A.); silvia.canepari@uniroma1.it (S.C.) \\ * Correspondence: antonella.giuliano@uniroma1.it
}

Received: 12 November 2019; Accepted: 16 December 2019; Published: 17 December 2019

\begin{abstract}
The aim of this work was to study the potential of food waste materials (banana peel, potato peel, apple peel, lemon peel, coffee waste, decaf coffee waste, grape waste, and carob peel) as low-cost adsorbents for the removal of aliphatic and aromatic volatile organic compounds (VOCs) from wastewater. The ability of examined food waste materials to adsorb VOCs from synthetic multi-component standard solutions was evaluated and the examined food waste materials showed high removal efficiency. Performances of coffee waste, grape waste, and lemon peel were detailed by using Trichloroethylene and p-Xylene in mono-component standard solutions. The adsorption capacity of the three selected food wastes was determined by using linear Langmuir and Freundlich isotherm models. Two errors functions, average percentage error (APE) and the chi-square test $\left(\chi^{2}\right)$, were used for isotherm optimization prediction. Freundlich isotherm well described the adsorption of VOCs on the considered materials. According to the obtained results, a multilayer, physical, and cooperative adsorption process was hypothesized, particularly evident when the VOCs' concentrations are high. This was confirmed by the high adsorption efficiency percentages $(E \%>$ $80 \%$ ) of VOCs from a real polluted matrix (urban solid waste leachate), containing high concentrations of total organic content.
\end{abstract}

Keywords: volatile organic compounds; adsorption; environmental remediation; food waste materials; wastewater treatment

\section{Introduction}

Volatile organic compounds (VOCs), aliphatic and aromatic, are a wide class of organic pollutants extensively released in the environment from a variety of anthropogenic sources such as fuel storage and transport, industrial operations [1], manufacture and storage of paints, and combustion processes [2]. Most of the VOCs can cause direct and indirect harmful effects to humans as well as the environment. Moreover, they represent one of the main causes of chronic contamination, especially in industrialized countries, since their chemical and physical properties enable them to persist in the environment. Chlorinated volatile organic compounds (Cl-VOCs) and aromatic hydrocarbons (BTEXs; benzene, toluene, and xylenes) are ubiquitous contaminants frequently detected in the environment. Therefore, human exposure to Cl-VOCs and BTEX is very common; they enter the body through multiple routes, such as inhalation, ingestion, and dermal absorption [3-5]. The toxicity of these compounds is increased by the fact that VOCs are strongly lipophilic with a capacity to concentrate in fat deposits by determining a long-term exposure [6,7]. Since the beginning of the 20th century, Cl-VOCs were extensively used as solvents for processes such as dry cleaning, production of pesticides, paints, 
and refrigerants $[8,9]$. Among them, Trichloroethylene is one of the most prevalent and persistent contaminants detected in polluted environments [10] and has been classified as group 2A by IARC (International Agency for Research on Cancer), as probably carcinogenic to humans [11]. In fact, exposure to Trichloroethylene seems to cause harmful effects on central nervous system and on the immune and endocrine systems in adults [12], and may also contribute to certain types of cancers in adults and children [9].

BTEXs, which have been found mainly in sites contaminated by petrol, gasoline, and petrochemical products [13,14], are well known carcinogens [12,15] that can adversely affect various human organs [16] by causing, for example, irritation of the eyes and reduction of bone marrow function [17]. Hence, it appears indispensable to eliminate these hazardous and mutagenic chemicals from the environment [18].

Several methods for wastewater decontamination from organic pollutants are reported [19-22]. Among these, the adsorption process has been efficaciously used for the removal of organic as well as inorganic compounds from wastewater because of its safety and ease in operation [23-26]. One of the most used materials to adsorb organic pollutants is activated carbon [25,27-29]; however, it has some disadvantages, such as the high cost and the environmental problems related to the regeneration and disposal of its waste [30,31]. During the past years, several studies have been focused on the evaluation of low-cost and environmentally friendly technologies for the removal of pollutants from wastewater. Most of these studies regarded low-cost materials, mainly biosorbents, which were found to be able to reduce availability and concentration of some organic compounds (mainly industrial organic dyes, polycyclic aromatic hydrocarbons, and phenolic compounds) [19,21,30-34].

Among the biosorbents, food waste materials appeared to be efficient for the removal of inorganic pollutants from wastewaters [35-41]. In a recent paper [42], food waste adsorbents were tested on a real polluted matrix and they showed high removal efficiency of various heavy metals. Biosorption by food waste materials has several benefits such as low production costs [43], free availability, and possible reuse of the biosorbents [44]. Moreover, it is essential to use waste as raw material for new products and new applications [45] as a renewable source of biomass [35]. The use of such residual materials might become a viable alternative for wastewater treatment with associated environmental and economic benefits [46].

Since the high danger of volatile organic compounds for humans and the environment along with the scarce amount of studies regarding the biosorption of VOCs by food waste materials, the evaluation of the performances of these materials as VOCs adsorbents constitutes an interesting issue that still should be investigated.

In this study, eight food waste materials (banana peel, potato peel, apple peel, lemon peel, coffee waste, decaf coffee waste, grape waste, and carob peel) were evaluated as potential low-cost biosorbents for the removal of VOCs from wastewater. With this aim, their adsorption efficiency and capacity of aliphatic/aromatic VOCs from multi-component and mono-component synthetic solutions and from a real polluted matrix were explored.

\section{Materials and Methods}

\subsection{Preparation of the Biosorbents}

Food waste powders $(n=8)$ were employed as low-cost adsorbents: banana peel, potato peel, apple peel, lemon peel, coffee waste, decaf coffee waste, grape waste and carob peel (Figure A1, Appendix A). Preparation of the biosorbents followed the procedure detailed in a recent study [42]. Briefly, food waste materials were sun-dried for a week, grinded with a mortar and sieved to retain particles sized between 0.25 and $0.125 \mathrm{~mm}$. The obtained powders were washed three times with deionized water (produced by an integrate water purification system; Arioso UP 900; Industrial Scientific Corporation, Pittsburg, PA, USA), dried at $55^{\circ} \mathrm{C}$ for $48 \mathrm{~h}$ in a vacutherm oven (Heraeus VT 
6025; Kendro Laboratory Products, Hanau, Germany), and then weighed on an analytical balance (Gibertini Europe 60; Gibertini Elettronica Srl, Milano, Italy).

\subsection{Adsorption Experiments}

First, removal efficiency of organic pollutants was explored by exposing each biosorbent to a synthetic multi-standard solution containing both aliphatic and aromatic VOCs (Trans-1,2-Dichloroethene, Dichloromethane, 1,1-Dichloroethene, 1,1-Dichloroethane, Chloroform, Carbon tetrachloride, Trichloroethylene, 1,2-Dichloropropane, 1,1,2-Trichloroethane, Tetrachloroethylene, Dibromochloromethane, 1,1,2-Tetrachloroethane, Bromoform, Methyl tert-butyl ether, Benzene, Toluene, Chlorobenzene, Ethylbenzene, m,p-Xylene, o-Xylene, 1,3-Dichlorobenzene, 1,4-Dichlorobenzene, 1,2-Dichlorobenzene). In these preliminary trials, $100 \mathrm{mg}$ of each adsorbent was exposed to $10 \mathrm{~mL}$ multi-standard solutions at $20 \mu \mathrm{g} / \mathrm{L}$ by using $20 \mathrm{~mL}$ glass vials, hermetically sealed. Multi-standard solutions were obtained by diluting $2 \mathrm{mg} / \mathrm{L}$ multi-component solution, prepared by mixing proper aliquots of aliphatic and aromatic standard stock solutions (SPEX CertiPrep, Metuchen, New Jersey, USA) in methanol.

The adsorption kinetic was assessed by keeping both the mass of each waste material $(100 \mathrm{mg})$ and the VOCs concentration $(20 \mu \mathrm{g} / \mathrm{L})$ constant, while increasing exposure time from $1 \mathrm{~h}$ to $24 \mathrm{~h}(1,2,3$, $4,5,6$, and $24 \mathrm{~h}$ ).

All the samples were analysed to determine the equilibrium concentration $\left(C_{e}\right)$, which is the amount of adsorbate remaining in solution after adsorption processes. Multi-component standard solutions without biosorbent were always treated together with each sample set, to trace and control possible VOCs' concentration variability due to loss by evaporation during treatment; VOCs' concentration of these solutions was used as initial concentration $\left(C_{0}\right)$.

The performances of the food waste materials as biosorbents in a real polluted matrix were tested by exposing $100 \mathrm{mg}$ of each food waste sorbent to $10 \mathrm{~mL}$ of an urban solid waste leachate. The same procedure described for the synthetic multi-standard solutions was applied to perform the exposure experiments and to determine $C_{0}$ and $C_{e}$. The total organic content (TOC) of this solution was measured by a TOC analyzer (TOC-VCSH; Shimadzu Corporation, Kyoto, Japan).

The $\mathrm{pH}$ of both multi-standard solutions and real polluted matrix, with and without biosorbents, was measured using a pH meter (Criston MicropH 2002, Crisonb Instruments, Barcelona, Spain).

According to results obtained from the just described preliminary trials, two selected target VOCs were chosen for deepening the study of adsorption behavior in synthetic mono-component solutions. Trichloroethylene and p-Xylene were representatives of aliphatic and aromatic classes, respectively. In these trials, adsorption capacity was calculated for three selected food wastes by varying VOCs' concentration in the range $25-2000 \mu \mathrm{g} / \mathrm{L}$ and by keeping constant at $100 \mathrm{mg}$ the adsorbent amount. Coffee waste, grape waste, and lemon peel were chosen for this experimental procedure as biosorbents, with reference to a recent paper in which all the considered food waste materials were characterized in detail by scanning electronic microscopy (SEM), Fourier transform infrared spectroscopy (FTIR), and principal component analysis (PCA) [40]. Specific surface areas were estimated by analyzing $1 \mathrm{~g}$ of each adsorbent by krypton gas physisorption (Porosimeter 3Flex 3500; Micromeritrics, GA, USA). Obtained values were included in the range $0.1-0.5 \mathrm{~m}^{2} / \mathrm{g}$. These values were close to the detection limit of the technique and the high uncertainties (about $0.05 \mathrm{~m}^{2} / \mathrm{g}$ ) did not allow a reliable comparison among materials.

Aromatic and aliphatic VOCs considered in this work were identified by comparison with the analytes registered in NIST Mass Spectral Library (1.6 NIST MS Software Version 2.3) of static headspace gas chromatography coupled to mass spectrometry (SHS-GC-MS) (probability of more than 70\%) and quantified. 


\subsection{GC Analysis}

Static headspace gas chromatography coupled to mass spectrometry (SHS-GC-MS; QHSS-40 Headspace sampler, QUMA Elektronik \& Analitik GmbH, Wuppertal, Germany; Varian 431-GC and Varian 210-MS, Varian, California, CA, USA) was used for all the VOCs' analyses. After having chosen the exposure time, the glass vials containing the solutions (with or without the biosorbent) were maintained under stirring for $23 \mathrm{~min}$ at the constant temperature of $80^{\circ} \mathrm{C}$, then $1 \mu \mathrm{L}$ of the vapor phase was injected in a capillary column (VF-624 $30 \mathrm{~m} \times 0.25 \mathrm{~mm} \times 1 \mu \mathrm{m}$; stationary phase composition: equivalent of a $6 \%$ cyanopropyl-phenyl/94\% dimethylpolysiloxane) with a Hamilton syringe (Hamilton Company, Bonaduz, Switzerland). Helium was used as carrier gas at the flow rate of $1 \mathrm{~mL} / \mathrm{min}$. The temperature was kept at $35^{\circ} \mathrm{C}$ for $2 \mathrm{~min}$, then it was increased to $50^{\circ} \mathrm{C}$ at the rate of $6{ }^{\circ} \mathrm{C}$ per minute and, lastly, to $180{ }^{\circ} \mathrm{C}$ at the rate of $12{ }^{\circ} \mathrm{C}$ per minute. The total duration of the chromatographic run was $16 \mathrm{~min}$.

Chromatograms were registered in selective ion monitoring mode (SIM) by selecting specific mass to charge ratios $(\mathrm{m} / \mathrm{z})$ for each analyte. The conditions employed to mass spectrometry and selected fragments and retention times of the considered VOCs and are summarized in Tables A1 and A2 (Appendix A), respectively.

Final volume of each analysed sample was $10 \mathrm{~mL}$ and all the experiments were performed in triplicate. External standard solutions were used for quantification.

\subsection{Calculation of Adsorption Efficiency and Adsorption Capacity}

Adsorption efficiency $(E \%)$ was calculated by the following equation:

$$
E \%=\left[\frac{\left(C_{0}-C_{e}\right)}{C_{0}}\right] \cdot 100 \%,
$$

where $C_{0}(\mu \mathrm{g} / \mathrm{L})$ is the inlet VOCs' concentration and $C_{e}(\mu \mathrm{g} / \mathrm{L})$ is the equilibrium concentration after the adsorption process.

Regarding real polluted matrix, for identified species, the adsorption efficiency was roughly estimated by comparing the peak areas in the presence $\left(A_{e}\right)$ and in the absence $\left(A_{0}\right)$ of the biosorbent $\left(E \%=\left[\frac{\left(A_{0}-A_{e}\right)}{A_{0}}\right] \cdot 100 \%\right)$ after adsorption processes.

Adsorption capacity $Q_{e}(\mu \mathrm{g} / \mathrm{g})$ was determined by following the procedure described in Wang et al. [47], using a mass equilibrium equation:

$$
Q_{e}=\frac{\left[\left(C_{0}-C_{e}\right) \cdot V\right]}{m},
$$

where $V$ is the volume of solution (L) inside the vial and $m$ is the amount (g) of food waste powder.

\subsection{Adsorption Isotherms}

The characterization of adsorption isotherms is considered one of the most appropriate methods for the assessment of the adsorbent capacity [47]. Adsorption isotherms play an important role in the predictive modelling procedures to understand what is going on during adsorption process and indicate how molecules, subjected to adsorption, distribute themselves between liquid and solid phases at equilibrium $[48,49]$. Linear regression analysis was used to obtain adjustable isotherm parameters. Table 1 summarizes the linear forms of Langmuir and Freundlich isotherm models used for this adsorption study. Although Langmuir isotherm model could be linearized into four different types, the reported Langmuir equation, defined Type I, is the most popular linear form used in available literature [50]. 
Table 1. Linear forms of Langmuir (Type I) and Freundlich isotherm models.

\begin{tabular}{cc}
\hline Isotherm Models & Linear \\
\hline Langmuir & $\frac{C_{e}}{Q_{e}}=\frac{1}{\left(K_{L} \cdot q_{m}\right)}+\frac{C_{e}}{q_{m}}$ \\
Freundlich & $\ln Q_{e}=\ln K_{F}+\left(\frac{1}{n} \cdot \ln C_{e}\right)$ \\
\hline
\end{tabular}

For Langmuir isotherms, $C_{e}(\mathrm{mg} / \mathrm{L})$ is the equilibrium concentration after adsorption process, $Q_{e}(\mathrm{mg} / \mathrm{g})$ is the adsorption capacity, $q_{m}(\mathrm{mg} / \mathrm{g})$ and $K_{L}(\mathrm{in} \mathrm{L} / \mathrm{mg})$ are sorption equilibrium constants. The constant $K_{L}$ is related to the free energy of adsorption and indicates affinity between the VOCs and the adsorbents [51].

In Freundlich isotherm, $K_{F}(\mathrm{mg} / \mathrm{L})$ and $n$ (dimensionless) are both constants indicative of sorption capacity and sorption intensity, respectively [52,53]. In particular, $n$ indicates the favorability of the adsorption process [52]; a close to unit $n$ value represents good adsorption capacity, meaning VOCs' adsorption is favorable [52]. The evaluation of the correlation coefficients $\left(R^{2}\right)$ is useful to predict which model best matches with the experimental data. In addition, the average percentage error (APE) and chi-square test $\left(\chi^{2}\right)$ values were calculated in order to verify the validity of the isotherm models. APE and $\chi^{2}$, defined ad distribution functions, indicate the fit between the experimental and the predicted values of the adsorption capacity [54] and were used for isotherm optimization prediction [49]: if data from the model are similar to the obtained experimental data, the function values will be small number. APE and $\chi^{2}$ were calculated as follows:

$$
\begin{aligned}
\operatorname{APE}(\%) & =\left[\frac{\sum_{i=1}^{N}\left|\frac{\left(Q_{e, e x p}-Q_{e, p r e)}\right)}{Q_{e, e x p}}\right|}{N}\right] \cdot 100, \\
\chi^{2} & =\sum_{i=1}^{N} \frac{\left(Q_{e, e x p}-Q_{e, p r e}\right)^{2}}{Q_{e, p r e}}
\end{aligned}
$$

where $Q_{e, e x p}, Q_{e, p r e}$ are experimental and predicted adsorption capacity, respectively; $N$ is the number of observations in the experimental data.

\section{Results and Discussion}

\subsection{Adsorption Efficiency from Multi-Component Solutions}

Preliminary tests on synthetic multi-component solutions were performed in order to verify the general behavior of the considered food waste materials as VOCs' biosorbents. First, the rate of the adsorption process was evaluated by exposing the materials to a synthetic mixture of aromatic and aliphatic VOCs for increasing times (1, 2, 3, 4, 5, 6, and $24 \mathrm{~h}$ ). As shown in Figure A2 (Appendix A), preliminary tests confirmed that $1 \mathrm{~h}$ contact time was enough to reach a steady-state VOC concentration, regarding both the liquid/solid and the liquid/gas interfaces. Consequently, all the successive samples were analysed after one hour from preparation.

Adsorption efficiency of each examined food waste material $(100 \mathrm{mg})$ from a mixture of aliphatic and aromatic VOCs at $20 \mu \mathrm{g} / \mathrm{L}$ is reported in Table 2. Data show that all the considered biosorbents exhibited some adsorption properties towards organic species; the efficiency of adsorption was very low for some compounds and for some investigated adsorbents, with some exceptions. Coffee and decaf coffee waste appeared to be the most efficient for the removal of most of the organic compounds. For example, among the aromatic compounds, p-Xylene, o-Xylene, 1,2-Dichlorobenzene, 1,3-Dichlorobenzene, and 1,4-Dichlorobenzene were adsorbed in high percentages $(E \%>50 \%)$; within the aliphatic compounds, Trichloroethylene, Tetrachloroethylene, and 1,1,2-Tetrachloroethane showed more than $40 \%$ of adsorption efficiency in presence of coffee and decaf coffee waste. Moreover, coffee waste was able to adsorb more than $90 \%$ of the Trans-1,2-Dichloroethene in multi-component solution. Apple peel seemed to be efficient for 1,1,2-Tetrachloroethane $(E \%>50 \%)$ and for 1,2-Dichlorobenzene, 
1,3-Dichlorobenzene and 1,4-Dichlorobenzene $(E \%>30 \%)$. Lastly, it is worth noting that also grape waste adsorption efficiency is considerable for 1,2-Dichlorobenzene, 1,3-Dichlorobenzene and 1,4-Dichlorobenzene $(E \%>40 \%)$ and 1,1,2-Tetrachloroethane $(E \%>50 \%)$.

In general, looking at Table 2, aromatic compounds seem to be more retained than the aliphatic; moreover, coffee waste, decaf coffee waste, grape waste, and banana peel showed fairly good adsorption efficiency for both aliphatic and aromatic compounds.

Considering the efficiency of the examined low-cost adsorbents for the removal of VOCs from synthetic solutions, other experimental tests were conducted to confirm the potential of the investigated food waste materials to adsorb organic compounds from a real polluted matrix. The chosen real polluted matrix had a very high total organic content $(\mathrm{TOC}=7500 \mathrm{mg} / \mathrm{L}$ ), and a spontaneous $\mathrm{pH}$ of 6.5 . In Table A3 (Appendix A), pH values both of multi-standard synthetic solutions and real polluted matrix are reported, with and without each adsorbent.

The real polluted matrix (a leachate of urban solid waste) contained a wide variety of VOCs; only some of them were identified by comparison with NIST library ( $>70 \%$ probability). The estimated adsorption efficiencies for these compounds are reported in Table 3. These data indicate that most of organic compounds is strongly retained by these adsorbents. In general, all the materials exhibited very good adsorption properties towards most of the VOCs and the results confirmed that coffee, decaf coffee, and grape waste were the most efficient biosorbents. Estimated efficiencies were much larger than those calculated in synthetic solutions. For example, coffee waste adsorption efficiency $(E \%)$ of Trichloroethylene was $43 \pm 2$ and $99 \pm 12$; lemon peel showed a Chlorobenzene $E \%$ of $10 \pm 1$ and $86 \pm$ 12 and grape waste showed a m, p-Xylene $E \%$ of $34 \pm 3$ and $96 \pm 5$ in synthetic and real polluted matrix, respectively. This behavior may be due to the different VOCs' concentration range in real polluted sample compared to the synthetic one, and seems to indicate a cooperative mechanism of adsorption, meaning an increase in the amount of pollutants adsorbed when initial VOCs' concentration was increased. Coffee waste, decaf coffee waste, and grape waste were confirmed to be the most efficient biosorbents for the removal of both aliphatic and aromatic VOCs.

\subsection{Adsorption Capacity from Synthetic Mono-Component Solutions}

Adsorption processes were further investigated by studying the adsorption isotherms of selected biosorbents and VOCs. Two selected target VOCs were chosen for deepening the study of adsorption behavior in synthetic mono-component solutions. Trichloroethylene and $\mathrm{p}$-Xylene were chosen as representative of aliphatic and aromatic classes, respectively. In these trials, VOCs' concentration was varied in the range of $25-2000 \mu \mathrm{g} / \mathrm{L}$, keeping constant at $100 \mathrm{mg}$ the adsorbent amount. Adsorption capacity was calculated for three selected food waste biosorbents (coffee waste, grape waste, and lemon peel) according to the results obtained from a previous study, in which all the considered food waste materials were analysed by scanning electronic microscopy (SEM) and Fourier transform infrared spectroscopy (FTIR) [42]. In this study, FTIR spectra were elaborated by principal component analysis (PCA) to group the food waste materials in different clusters, according to functional groups present on the adsorbents' surfaces. First cluster included orange and lemon peel, and was characterized by $\mathrm{OH}$ of alcohols, phenols and carboxylic acids; $\mathrm{CH}, \mathrm{COC}, \mathrm{CN}, \mathrm{PO}$ of polysaccharides and $\mathrm{C}=\mathrm{C}$ of lipids and lignin moieties; lemon peel was chosen as representative of this cluster.

Second cluster included coffee and decaf coffee waste, apple, and banana peel, and was characterized by the highest amount of $\mathrm{CH}$ bonds of methyl and methylene groups of lipids; coffee waste was chosen as representative of this cluster. Third cluster included grape waste and carob peel and was characterized by the lowest amount of the identified functional groups; grape waste was chosen as representative of this cluster.

Adsorption capacity of coffee waste, grape waste and lemon peel towards Trichloroethylene and p-Xylene is graphically represented in Figure 1. Plots $a, b$, and c show the adsorption curves of coffee waste, grape waste, and lemon peel for Trichloroethylene. As expected, the adsorption capacity of the three low-cost sorbents increases with increasing the pollutant exposure concentration. 
Trichloroethylene was adsorbed with the highest values of $Q_{e}(\mu \mathrm{g} / \mathrm{g})$ in presence of coffee waste, while grape waste and lemon peel were found to be less efficient. Adsorption capacity curves show a quite complex trend and seem to indicate that the adsorbent saturation was reached at the tested conditions. Figure 1 (plots d, e, f), shows the adsorption curves of coffee waste, grape waste, and lemon peel for $\mathrm{p}$-Xylene. The trend of adsorption curves of $\mathrm{p}$-Xylene with all the three biosorbents was in general quite similar to that seen for Trichloroethylene: an increase of adsorption capacity is observed with the increase of pollutant's concentration. p-Xylene adsorption capacity appeared to be higher than that of Trichloroethylene for all the examined food waste materials. For example, coffee waste adsorption capacity can be recalled: the highest $Q_{e}$ value reached with Trichloroethylene and $p-X y l e n e$ was $30 \mu \mathrm{g} / \mathrm{g}$ and $80 \mu \mathrm{g} / \mathrm{g}$, respectively.

Table 2. Adsorption efficiency ( $E \% ; 100 \mathrm{mg}$ of each biosorbent) of aliphatic and aromatic VOCs from multi-component synthetic solution $(20 \mu \mathrm{g} / \mathrm{L})$. Mean $\pm \mathrm{SD}$ of three replicates is reported.

\begin{tabular}{|c|c|c|c|c|c|c|c|c|}
\hline \multicolumn{9}{|c|}{ Adsorption Efficiency $(E \%) \pm$ SD } \\
\hline Aliphatic VOCs & $\begin{array}{c}\text { Banana } \\
\text { Peel }\end{array}$ & $\begin{array}{c}\text { Potato } \\
\text { Peel }\end{array}$ & $\begin{array}{c}\text { Apple } \\
\text { Peel }\end{array}$ & $\begin{array}{c}\text { Lemon } \\
\text { Peel }\end{array}$ & $\begin{array}{l}\text { Coffee } \\
\text { Waste }\end{array}$ & $\begin{array}{l}\text { Decaf C. } \\
\text { Waste }\end{array}$ & $\begin{array}{l}\text { Grape } \\
\text { Waste }\end{array}$ & $\begin{array}{c}\text { Carob } \\
\text { Peel }\end{array}$ \\
\hline Trans-1,2-Dichloroethene & $2.7 \pm 0.4$ & $0.6 \pm 0.2$ & $0.7 \pm 0.4$ & $1.6 \pm 0.8$ & $93 \pm 18$ & $7.6 \pm 1.4$ & $4.7 \pm 1.6$ & $2.3 \pm 1.6$ \\
\hline Dichloromethane & $3.9 \pm 0.2$ & $5.7 \pm 4.3$ & $8.2 \pm 3.2$ & $7.1 \pm 1.8$ & $9.8 \pm 0.7$ & $13 \pm 1$ & $6.2 \pm 1.9$ & $3.7 \pm 1.1$ \\
\hline 1,1-Dichloroethene & $1.8 \pm 0.3$ & $1.1 \pm 0.7$ & $3.3 \pm 0.8$ & $3.1 \pm 1.8$ & $3.9 \pm 0.5$ & $12 \pm 5$ & $6.7 \pm 1.2$ & $1.7 \pm 1.3$ \\
\hline 1,1-Dichloroethane & $1.3 \pm 0.8$ & $5.6 \pm 1.9$ & $2.6 \pm 0.2$ & $13 \pm 6$ & $12 \pm 2$ & $16 \pm 1$ & $6.7 \pm 1.7$ & $3.1 \pm 1.3$ \\
\hline Chloroform & $5.9 \pm 5.4$ & $7.2 \pm 2.4$ & $1.5 \pm 0.5$ & $5.1 \pm 2.6$ & $6.2 \pm 2.3$ & $13 \pm 1$ & $6.3 \pm 1.1$ & $7.7 \pm 3.1$ \\
\hline Carbon tetrachloride & $39 \pm 2$ & $4.3 \pm 1.9$ & $11 \pm 2$ & $6.3 \pm 0.3$ & $17 \pm 2$ & $16 \pm 5$ & $37 \pm 12$ & $4.3 \pm 1.7$ \\
\hline Trichloroethylene & $35 \pm 1$ & $16 \pm 13$ & $36 \pm 1$ & $44 \pm 1$ & $43 \pm 2$ & $51 \pm 1$ & $34 \pm 2$ & $36 \pm 1$ \\
\hline 1,2-Dichloropropane & $1.1 \pm 0.2$ & $0.9 \pm 0.5$ & $8.3 \pm 6.4$ & $4.7 \pm 2.1$ & $1.1 \pm 0.2$ & $16 \pm 1$ & $5.5 \pm 3.2$ & $3.8 \pm 3.4$ \\
\hline $1,1,2$-Trichloroethane & $7.5 \pm 6.5$ & $5.4 \pm 4.3$ & $13 \pm 5$ & $14 \pm 4$ & $18 \pm 4$ & $25 \pm 9$ & $11 \pm 1$ & $2.5 \pm 0.9$ \\
\hline Tetrachloroethylene & $17 \pm 12$ & $12 \pm 4$ & $11 \pm 4$ & $1.8 \pm 0.9$ & $35 \pm 9$ & $47 \pm 10$ & $42 \pm 7$ & $11 \pm 2$ \\
\hline Dibromochloromethane & $43 \pm 5$ & $1.1 \pm 0.8$ & $2.5 \pm 1.8$ & $1.4 \pm 0.8$ & $13 \pm 1$ & $27 \pm 3$ & $11 \pm 2$ & $0.8 \pm 0.3$ \\
\hline 1,1,2-Tetrachloroethane & $39 \pm 1$ & $23 \pm 2$ & $57 \pm 7$ & $38 \pm 1$ & $73 \pm 13$ & $77 \pm 1$ & $51 \pm 1$ & $8.5 \pm 1.8$ \\
\hline Bromoform & $57 \pm 2$ & $1.6 \pm 0.9$ & $17 \pm 4$ & $1.3 \pm 0.6$ & $19 \pm 2$ & $25 \pm 2$ & $25 \pm 2$ & $2.3 \pm 0.7$ \\
\hline \multicolumn{9}{|l|}{ Aromatic VOCs } \\
\hline Methyl tert-butyl ether & $1.8 \pm 0.2$ & $9.5 \pm 1.9$ & $1.8 \pm 0.8$ & $3.1 \pm 2.3$ & $10 \pm 5$ & $1.5 \pm 1.4$ & $1.5 \pm 1.1$ & $1.5 \pm 1.1$ \\
\hline Benzene & $1.8 \pm 0.8$ & $2.8 \pm 0.3$ & $1.8 \pm 0.2$ & $1.3 \pm 1.2$ & $17 \pm 1$ & $19 \pm 1$ & $7.1 \pm 0.5$ & $5.9 \pm 0.3$ \\
\hline Toluene & $12 \pm 1$ & $1.5 \pm 1.1$ & $8.5 \pm 0.5$ & $3.9 \pm 0.3$ & $31 \pm 2$ & $33 \pm 2$ & $19 \pm 2$ & $1.3 \pm 0.8$ \\
\hline Chlorobenzene & $17 \pm 1$ & $5.5 \pm 0.5$ & $15 \pm 1$ & $10 \pm 1$ & $37 \pm 1$ & $42 \pm 1$ & $30 \pm 1$ & $2.5 \pm 2.1$ \\
\hline Ethylbenzene & $7.1 \pm 1.4$ & $4.8 \pm 1.8$ & $9.5 \pm 5.5$ & $1.5 \pm 0.7$ & $28 \pm 1$ & $37 \pm 3$ & $24 \pm 17$ & $1.6 \pm 0.4$ \\
\hline m, p-Xylene & $35 \pm 1$ & $12 \pm 1$ & $21 \pm 1$ & $15 \pm 1$ & $54 \pm 1$ & $56 \pm 1$ & $34 \pm 3$ & $3.3 \pm 1.8$ \\
\hline o-Xylene & $28 \pm 1$ & $14 \pm 3$ & $24 \pm 1$ & $18 \pm 4$ & $57 \pm 1$ & $58 \pm 1$ & $33 \pm 5$ & $13 \pm 2$ \\
\hline 1,3-Dichlorobenzene & $35 \pm 2$ & $12 \pm 1$ & $34 \pm 1$ & $19 \pm 2$ & $67 \pm 1$ & $73 \pm 2$ & $48 \pm 4$ & $12 \pm 1$ \\
\hline 1,4-Dichlorobenzene & $43 \pm 2$ & $14 \pm 1$ & $36 \pm 2$ & $20 \pm 1$ & $68 \pm 1$ & $71 \pm 1$ & $47 \pm 1$ & $24 \pm 1$ \\
\hline 1,2-Dichlorobenzene & $36 \pm 1$ & $10 \pm 2$ & $37 \pm 1$ & $20 \pm 2$ & $67 \pm 1$ & $73 \pm 2$ & $47 \pm 2$ & $13 \pm 2$ \\
\hline
\end{tabular}

These results agree with those obtained from the adsorption experiments in multi-component standard solutions. Coffee waste was found to be the most efficient biosorbent for the removal of both Trichloroethylene and p-Xylene. The most plausible explanation comes from the chemical-physical properties of Trichloroethylene, p-Xylene, and coffee waste composition. FTIR spectra of coffee waste showed peaks of asymmetric and symmetric stretching of hydrophobic C-H bonds of methyl and methylene groups, attributed to the presence of lipids that are available in coffee samples in large amount $[42,55]$. Considering that Trichloroethylene and p-Xylene are both well-known lipophilic compound [56,57], a significant adsorption on lipid-rich coffee waste was expected. Moreover, according to the SEM micrographs, coffee waste has very porous surface [42] that allows it to adsorb a higher amount of pollutants from wastewater. Finally, lemon peel turned out to be the least efficient adsorbent for Trichloroethylene and p-Xylene with the highest $Q_{e}$ recorded value of $10 \mu \mathrm{g} / \mathrm{g}$ and $20 \mu \mathrm{g} / \mathrm{g}$, respectively, probably because of its less porous surface and the presence of polar functional groups [42]. 
Table 3. Adsorption efficiency (E\%; $100 \mathrm{mg}$ of each biosorbent) of VOCs from real polluted matrix of urban solid waste leachate. Mean \pm SD of three replicates is reported.

\begin{tabular}{|c|c|c|c|c|c|c|c|c|}
\hline \multicolumn{9}{|c|}{ Adsorption Efficiency $(E \%) \pm \mathrm{SD}$} \\
\hline Aliphatic VOCs & $\begin{array}{c}\text { Banana } \\
\text { Peel }\end{array}$ & $\begin{array}{c}\text { Potato } \\
\text { Peel }\end{array}$ & $\begin{array}{c}\text { Apple } \\
\text { Peel }\end{array}$ & $\begin{array}{c}\text { Lemon } \\
\text { Peel }\end{array}$ & $\begin{array}{l}\text { Coffee } \\
\text { Waste }\end{array}$ & $\begin{array}{c}\text { Decaf C. } \\
\text { Waste }\end{array}$ & $\begin{array}{l}\text { Grape } \\
\text { Waste }\end{array}$ & $\begin{array}{c}\text { Carob } \\
\text { Peel }\end{array}$ \\
\hline 1,1-Dichloroethene & $20 \pm 5$ & $38 \pm 9$ & $60 \pm 10$ & $79 \pm 18$ & $91 \pm 16$ & $89 \pm 5$ & $87 \pm 6$ & $71 \pm 11$ \\
\hline Dichloromethane & $85 \pm 11$ & $85 \pm 15$ & $90 \pm 18$ & $96 \pm 15$ & $97 \pm 9$ & $97 \pm 5$ & $97 \pm 10$ & $93 \pm 7$ \\
\hline Chloroform & $24 \pm 9$ & $13 \pm 6$ & $54 \pm 12$ & $83 \pm 14$ & $92 \pm 10$ & $93 \pm 5$ & $90 \pm 9$ & $69 \pm 16$ \\
\hline Trichloroethylene & $44 \pm 8$ & $39 \pm 6$ & $56 \pm 13$ & $98 \pm 16$ & $99 \pm 12$ & $96 \pm 6$ & $97 \pm 10$ & $86 \pm 9$ \\
\hline $\begin{array}{l}\text { Dibromochloromethane } \\
\text { Aromatic VOCs }\end{array}$ & $8.6 \pm 2.3$ & $3.2 \pm 1.4$ & $47 \pm 14$ & $84 \pm 10$ & $95 \pm 11$ & $93 \pm 2$ & $89 \pm 8$ & $67 \pm 6$ \\
\hline Toluene & $31 \pm 9$ & $14 \pm 7$ & $59 \pm 10$ & $79 \pm 18$ & $93 \pm 9$ & $91 \pm 9$ & $89 \pm 15$ & $62 \pm 8$ \\
\hline Chlorobenzene & $45 \pm 8$ & $15 \pm 6$ & $67 \pm 18$ & $86 \pm 12$ & $97 \pm 9$ & $93 \pm 5$ & $93 \pm 7$ & $71 \pm 7$ \\
\hline m, p-Xylene & $64 \pm 9$ & $27 \pm 11$ & $78 \pm 10$ & $91 \pm 14$ & $99 \pm 10$ & $98 \pm 2$ & $96 \pm 5$ & $77 \pm 10$ \\
\hline o-Xylene & $72 \pm 11$ & $26 \pm 13$ & $78 \pm 12$ & $92 \pm 17$ & $93 \pm 9$ & $95 \pm 8$ & $97 \pm 9$ & $78 \pm 9$ \\
\hline 1,3-Dichlorobenzene & $77 \pm 13$ & $37 \pm 15$ & $93 \pm 18$ & $98 \pm 10$ & $98 \pm 7$ & $98 \pm 2$ & $97 \pm 11$ & $87 \pm 7$ \\
\hline
\end{tabular}

\subsection{Adsorption Isotherms}

Sorption equilibrium data for the two VOCs and the three food waste materials were fitted to the Langmuir and Freundlich isotherm models. Although many adsorption models were developed and applied in the literature [58,59], the Langmuir and Freundlich adsorption models are frequently used to describe adsorption mechanism. Although nonlinear isotherm forms are recommended in the field of batch adsorption research to avoid errors resulting from simple linear regression [49,60], in this study, linearized isotherm models were adopted due to the mathematical simplicity [51] and to immediately obtain semi-quantitative isotherm constants. Equilibrium data did not fit Langmuir model for both the studied VOCs and for the considered biosorbents. Since Langmuir isotherm cannot be applied in this work, the corresponding data are not reported. Linearized Freundlich adsorption isotherms for Trichloroethylene and p-Xylene are reported in Figure 2.

The constants obtained by applying the Freundlich isotherm model are summarized in Table 4. The high correlation coefficients $\left(R^{2} \geq 0.9\right)$ obtained by plotting $\log Q_{e}$ versus $\log C_{e}$ for both Trichloroethylene and $\mathrm{p}$-Xylene indicate that these adsorption processes are well represented by the Freundlich model. Lemon peel showed a lower correlation, but it's still significant.

Moreover, the values of $n$ and $K_{F}$ of the Freundlich model indicate good adsorption intensity and capacity, respectively: $n$ was close to unity for all the examined food waste adsorbents and for both Trichloroethylene and p-Xylene, indicating that VOCs adsorption is favorable [52]. Furthermore, the low values of $A P E$ and $\chi^{2}$ in association with higher $R^{2}$ generate a satisfactory fit of Freundlich model to the experimental data, even if they are little higher for lemon peel. To explain these contrasting results, the adsorption processes simulated by the two models are to be considered. Langmuir model represents only monolayer adsorption processes [46] on the outer surface of the adsorbent, without considering any further adsorption [61]. Instead, Freundlich isotherm represents heterogeneous surfaces and sorbent systems [47,62] in aqueous systems [30], in which multilayer adsorption processes are included. According to the increase of the adsorption capacity with increasing of the VOCs' concentration, a multilayer adsorption process can be hypothesized. This is also confirmed by the $n$ values reported in Table 4 . In fact, when $n<1$, the presence of an isotherm called "solvent-affinity isotherm" is suggested [62]; this kind of isotherm represents an increase of the adsorption energy with increasing concentration of pollutants on the adsorbents' surface. Thus, it can be assumed that aliphatic and aromatic VOCs are initially weakly detained by food waste materials through an adsorption on the active sites of the sorbents. At high concentrations, the active sites are completely occupied by the compounds and the adsorption of other pollutants is supported by Van der Waals forces with the molecules already adsorbed, making a physical adsorption within adsorbent layers. The result is an effective adsorption process within the adsorbent layers, caused by strong intermolecular attractions. 

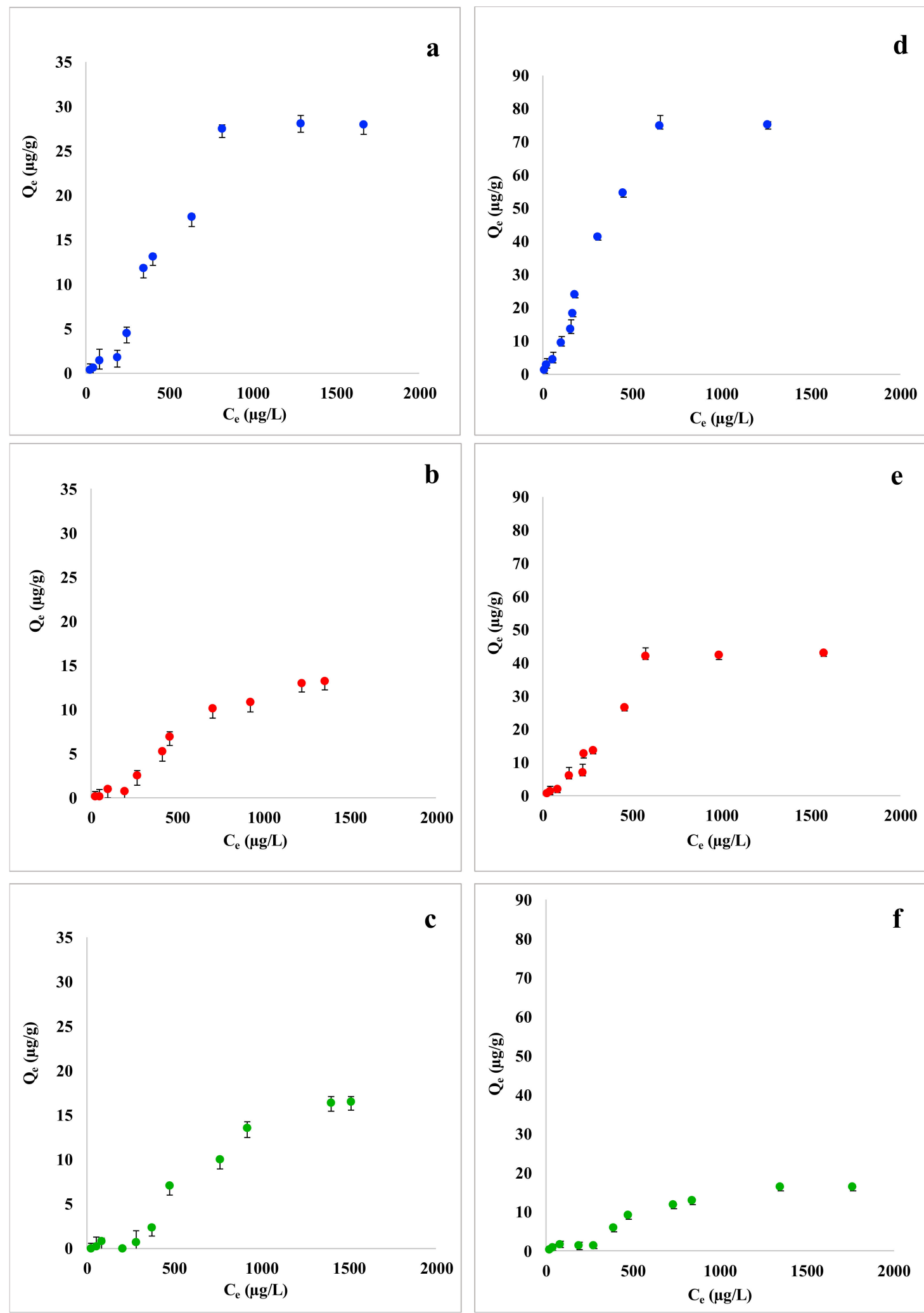

Figure 1. Comparison of adsorption capacity $\left(Q_{e}, \mu \mathrm{g} / \mathrm{g}\right)$ isotherms of (a) coffee waste, $(\mathbf{b})$ grape waste, and (c) lemon peel with Trichloroethylene (from 25 to $2000 \mu \mathrm{g} / \mathrm{L} ; 100 \mathrm{mg}$ of each biosorbent) and (d) coffee waste, (e) grape waste, and (f) lemon peel with p-Xylene (from 25 to $2000 \mu \mathrm{g} / \mathrm{L} ; 100 \mathrm{mg}$ of each biosorbent). Mean $\pm \mathrm{SD}$ of three replicates is reported. 


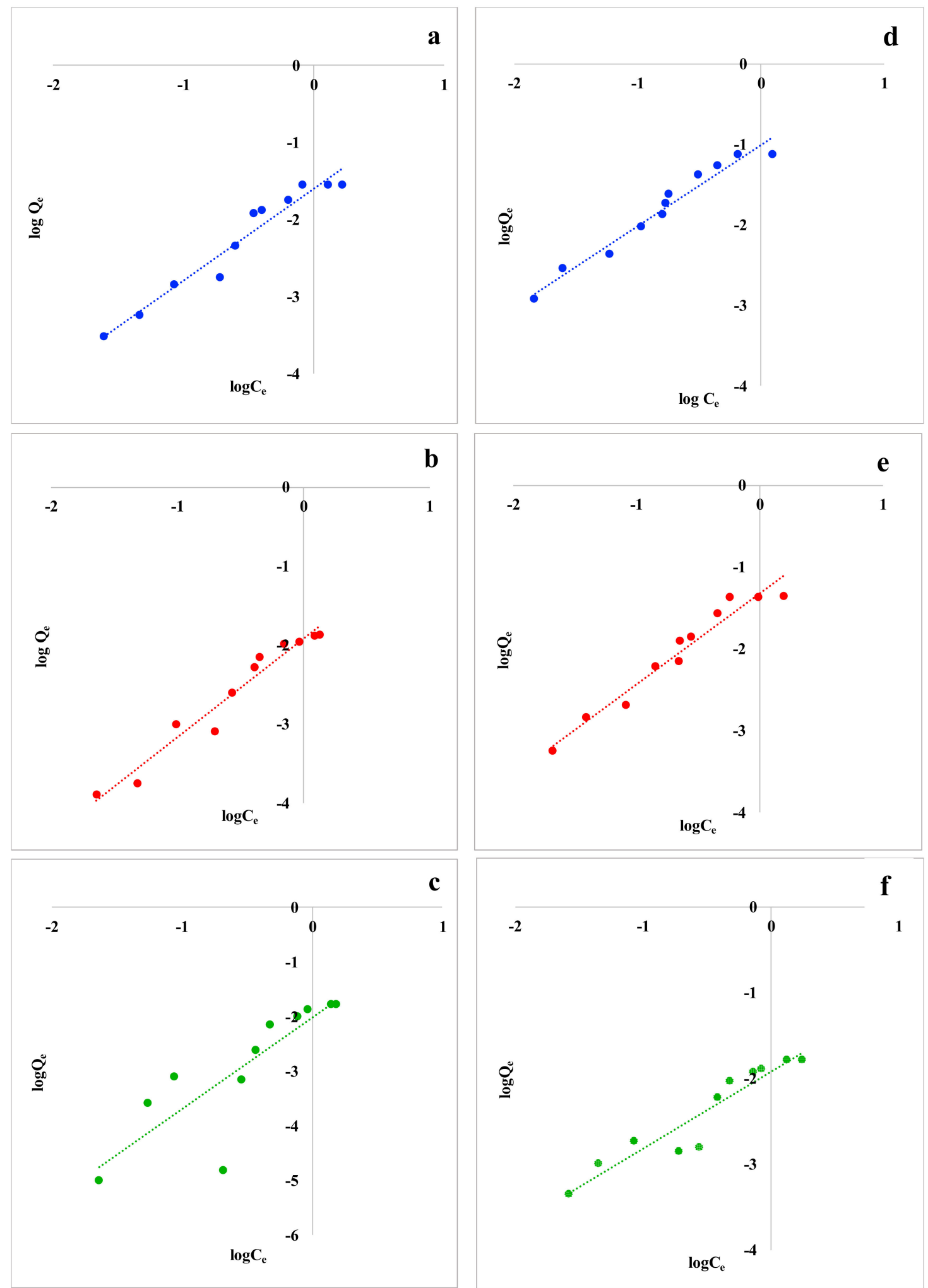

Figure 2. Freundlich isotherms for Trichloroethylene with (a) coffee waste, (b) grape waste, and (c) lemon peel; Freundlich isotherms for p-Xylene with (d) coffee waste, (e) grape waste, and (f) lemon peel. 
Table 4. Parameters of Freundlich isotherm for Trichloroethylene and p-Xylene.

\begin{tabular}{cccccc}
\hline & $K_{F}(\mathrm{mg} / \mathrm{L})$ & $n$ & $\boldsymbol{R}^{2}$ & APE $(\%)$ & $\chi^{2}$ \\
\hline Trichloroethylene & & & & & \\
Coffee waste & 0.026 & 0.83 & 0.99 & 2.9 & $3.1 \times 10^{-5}$ \\
Grape waste & 0.012 & 0.79 & 0.99 & 5 & $1.8 \times 10^{-5}$ \\
Lemon peel & 0.009 & 0.61 & 0.97 & 22 & $1.3 \times 10^{-5}$ \\
p-Xylene & & & & & \\
Coffee waste & 0.11 & 0.98 & 0.99 & 0.91 & $1.2 \times 10^{-5}$ \\
Grape waste & 0.051 & 0.89 & 0.98 & 0.86 & $3.4 \times 10^{-6}$ \\
Lemon peel & 0.012 & 1.1 & 0.97 & 8 & $1.1 \times 10^{-3}$ \\
\hline
\end{tabular}

\section{Conclusions}

Food waste materials, that are available in large amount and at very low costs, appeared to be promising biosorbents for both aliphatic and aromatic VOCs in aqueous solutions. In general, the aromatic VOCs were better adsorbed than the aliphatic by most of the considered materials. This is confirmed by the high percentages of adsorption efficiency $(E \%)$.

Adsorption capacities $\left(Q_{e}\right)$ of three chosen food waste materials (coffee waste, grape waste, and lemon peel) with Trichloroethylene (chosen as representative of aromatic VOCs) and p-Xylene (chosen as representative of aliphatic Cl-VOCs) were investigated; coffee waste resulted the most efficient sorbent for the removal of both considered VOCs. This is probably due to the presence of lipids in coffee samples on which Trichloroethylene and p-Xylene compounds are efficiently adsorbed, due to their lipophilic nature.

Adsorption equilibrium isotherms showed that coffee waste is the most efficient material for both p-Xylene and Trichloroethylene adsorption. In all the examined systems, the sorption processes followed much more closely the Freundlich than the Langmuir isotherm model. This indicates a physical adsorption mechanism thanks to London-Van der Waals forces between solute and sorbent, through a cooperative adsorption mechanism, in which the already adsorbed molecules on the sorbent's surface facilitate the adsorption of other molecules. This kind of physical adsorption may be particularly beneficial in field applications, because it gives the adsorbents an opportunity to have great adsorption performance at high pollutant concentrations.

Evaluation of food waste performances as biosorbents in field still needs further deepening, such as the effects of $\mathrm{pH}$ on removal capacity, the assessment of the effects of sorbents' particle size, the investigation of repetitive adsorption desorption cycles for material reusability investigation, or even the comparison between other food waste materials' adsorption capacity. Taking into account all the considerations, the results of this preliminary study suggest further investigations about the possible applicative use of these low-cost adsorbents for VOCs' removal from wastewater.

In this context, the efficient adsorption capacity of food waste materials at high VOCs' concentration was preliminarily confirmed by the excellent adsorption efficiencies obtained in a real polluted matrix.

Author Contributions: Conceptualization, M.A.F., S.C., and A.G.; Data curation, M.A.F. and L.M.; Formal analysis, M.A.F. and A.G.; Methodology, M.A.F. and A.G.; Supervision, M.L.A. and S.C.; Writing-original draft, M.A.F.; Writing, review \& editing, M.A.F., L.M. and S.C.

Funding: This research received no external funding.

Acknowledgments: The authors gratefully thank Rosanna Congedo (Higher Education Institution “Quinto Ennio", Gallipoli, Italy) and Andrea Masotti (Children's Hospital Bambino Gesù-IRCCS Research Laboratories, Rome, Italy) for providing food waste materials, Isabella Masia for collaborating to the experimental tests, Iqra Javed for providing language help, and Federica Castellani for supporting manuscript revision.

Conflicts of Interest: The authors declare no conflicts of interest. 


\section{Appendix A}

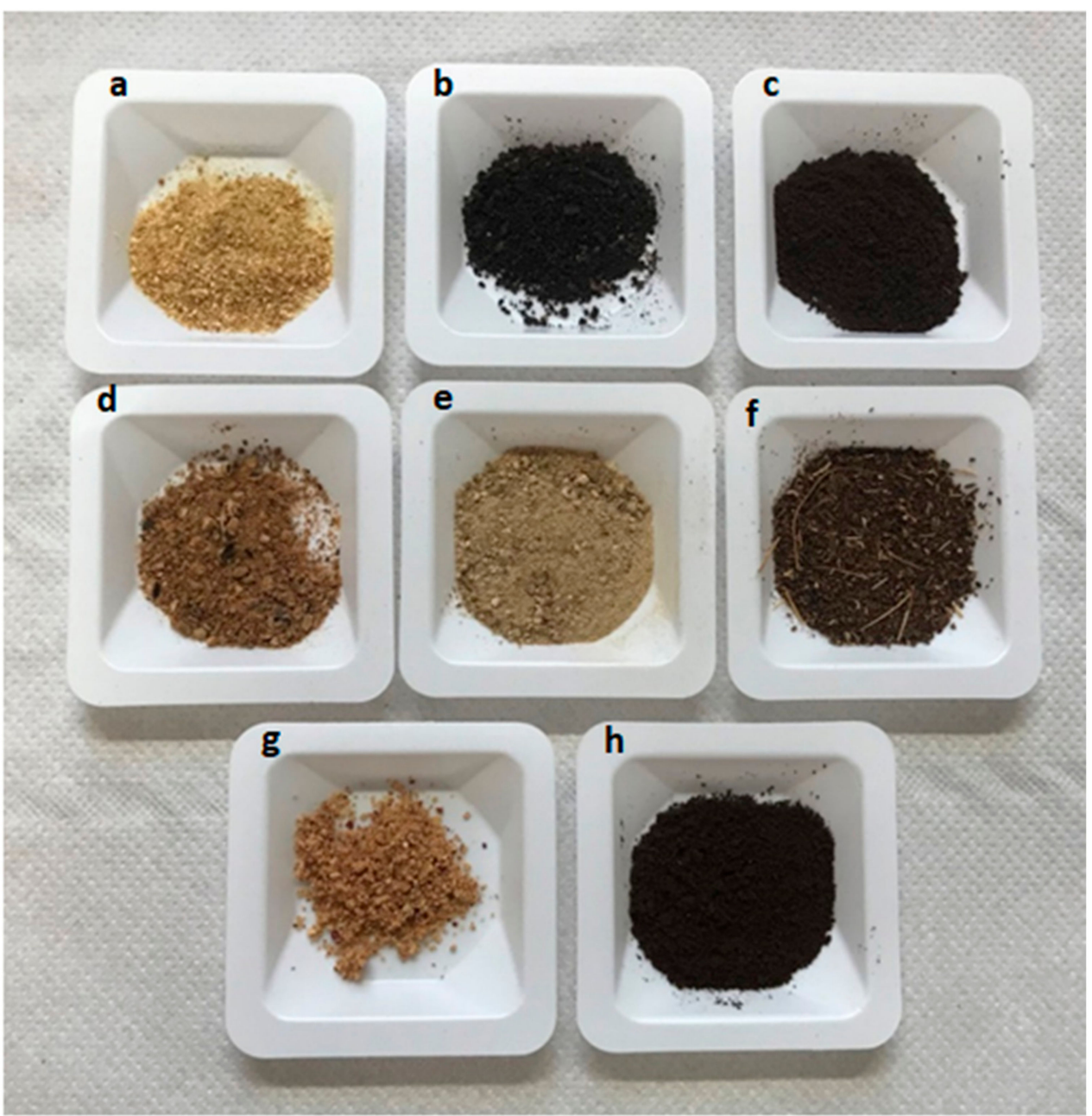

Figure A1. Food waste powders: (a) lemon peel, (b) grape waste, (c) coffee waste, (d) carob peel, (e) potato peel, (f) banana peel, (g) apple peel, (h) decaf coffee waste.

Table A1. Conditions employed to mass spectrometry (Varian 210-MS ion trap mass spectrometer with electron ionization).

\begin{tabular}{cccc}
\hline Acquisition Method & $\begin{array}{c}\text { Ion Trap } \\
\text { Temperature }\left({ }^{\circ} \mathrm{C}\right)\end{array}$ & $\begin{array}{c}\text { Transfer Line } \\
\text { Temperature }\left({ }^{\circ} \mathrm{C}\right)\end{array}$ & $\begin{array}{c}\text { Vacuum Manifold } \\
\text { Temperature }\left({ }^{\circ} \mathbf{C}\right)\end{array}$ \\
\hline $\begin{array}{c}\text { SIM (Single Ion } \\
\text { Monitoring) }\end{array}$ & $150{ }^{\circ} \mathrm{C}$ & $180{ }^{\circ} \mathrm{C}$ & $80{ }^{\circ} \mathrm{C}$ \\
\hline
\end{tabular}

Table A2. GC-MS parameters for VOCs analyses.

\begin{tabular}{cccc}
\hline VOCs & Retention Time (min) & Fragments (m/z) & Acquisition Range (m/z) \\
\hline Aliphatic VOCs & & & \\
Trans-1,2-Dichloroethene & $4.50-4.90$ & $61-96-98$ & $55-100$ \\
Dichloromethane & $3.90-4.50$ & $49-84-86$ & $49-90$ \\
1,1-Dichloroethene & $3.20-3.90$ & $61-96-98$ & $60-100$ \\
1,1-Dichloroethane & $4.90-5.50$ & $63-65-27$ & $60-90$ \\
Chloroform & $5.50-6.55$ & $83-85-47$ & $45-90$ \\
Carbon tetrachloride & $6.70-6.90$ & $117-121$ & $75-125$ \\
Trichloroethylene & $7.40-7.95$ & $130-95-97$ & $55-135$ \\
1,2-Dichloropropane & $7.95-8.25$ & $63-62-27$ & $60-80$ \\
\hline
\end{tabular}


Table A2. Cont.

\begin{tabular}{cccc}
\hline VOCs & Retention Time (min) & Fragments $(\mathbf{m} / \mathbf{z})$ & Acquisition Range $(\mathbf{m} / \mathbf{z})$ \\
\hline 1,1,2-Trichloroethane & $9.70-9.86$ & $97-83-61$ & $44-170$ \\
Tetrachloroethylene & $9.86-10.10$ & $166-164-129$ & $160-175$ \\
Dibromochloromethane & $10.10-10.75$ & $129-127$ & $80-132$ \\
1,1,2-Tetrachloroethane & $11.78-11.87$ & $81-82.8-83.8$ & $80-85$ \\
Bromoform & $11.73-12.02$ & $173-171$ & $75-180$ \\
Aromatic VOCs & & & \\
Methyl tert-butyl ether & $1.11-2.10$ & $44.8-45.8$ & $40-48$ \\
Benzene & $6.9-7.08$ & $78-77$ & $45-80$ \\
Toluene & $9.15-9.45$ & $91-92$ & $60-100$ \\
Chlorobenzene & $10.75-11.00$ & $112-77-114$ & $48-120$ \\
Ethylbenzene & $11.00-11.13$ & $91-106$ & $85-110$ \\
m-Xylene & $11.30-11.73$ & $91-106$ & $70-120$ \\
p-Xylene & $11.30-11.73$ & $91-106$ & $70-120$ \\
o-Xylene & $11.13-11.30$ & $91-106$ & $70-120$ \\
1,3-Dichlorobenzene & $12.75-13.71$ & $146-148-111$ & $70-150$ \\
1,4-Dichlorobenzene & $13.71-13.85$ & $146-148-111$ & $70-150$ \\
1,2-Dichlorobenzene & $13.85-15.00$ & $146-148-111$ & $70-150$ \\
\hline
\end{tabular}

60

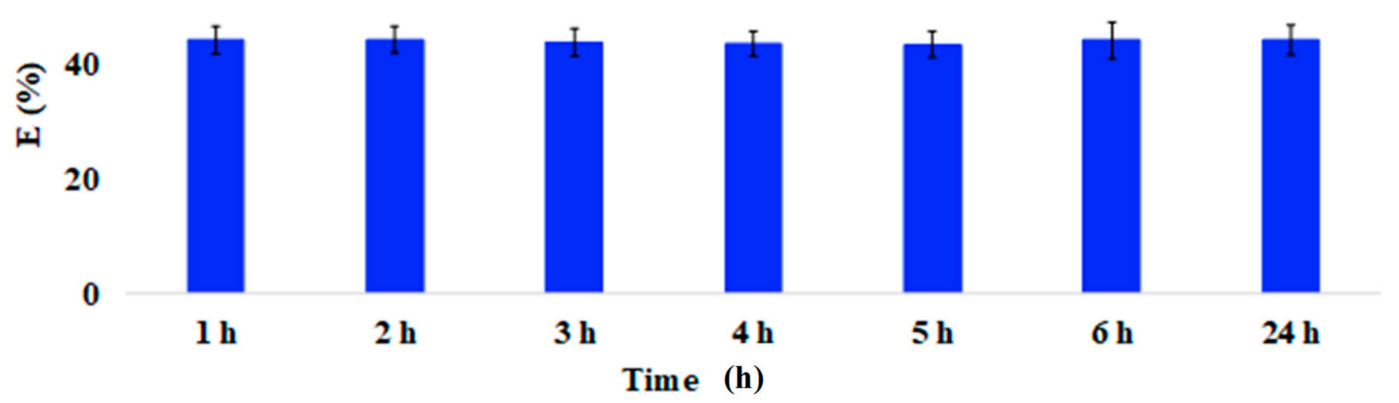

Figure A2. Adsorption efficiency (E\%; $100 \mathrm{mg}$ of coffee waste) of Trichloroethylene after 1, 2, 3, 4, 5,6 and $24 \mathrm{~h}$ from preparation. Mean \pm SD of three replicates is reported. The adsorption kinetic was assessed by keeping both the mass of each waste material $(100 \mathrm{mg})$ and the VOCs' concentration $(20 \mu \mathrm{g} / \mathrm{L})$ constant, while increasing exposure time from $1 \mathrm{~h}$ to $24 \mathrm{~h}(1,2,3,4,5,6$, and $24 \mathrm{~h})$.

Table A3. $\mathrm{pH}$ of real polluted matrix and synthetic multi-component standard solution with and without the eight food waste materials.

\begin{tabular}{ccc}
\hline Food Waste Materials & Real Polluted Matrix & $\begin{array}{c}\text { Synthetic Multi-Component } \\
\text { Standard Solution }\end{array}$ \\
\hline Without adsorbents & 6.5 & 7 \\
Banana peel & 5.5 & 5.8 \\
Potato peel & 6.4 & 7.5 \\
Apple peel & 5.9 & 4.7 \\
Lemon peel & 4.7 & 4.7 \\
Coffee waste & 6.2 & 5.9 \\
Grape waste & 6.1 & 7.1 \\
Carob peel & 5.9 & 5.3 \\
Decaf Coffee waste & 6.5 & 6.2 \\
\hline
\end{tabular}

\section{References}

1. Atkinson, R. Atmospheric chemistry of VOCs and NOx. Atmos. Environ. 2000, 34, 2063-2101. [CrossRef]

2. Evuti, A.M. A synopsis on biogenic and anthropogenic volatile organic compounds emissions: Hazards and control. Int. J. Eng. 2013, 2, 145. 
3. Kim, J.; Lee, S.S.; Khim, J. Peat moss-derived biochars as effective sorbents for VOCs' removal in groundwater. Environ. Geochem. Health 2010, 41, 1637-1646. [CrossRef] [PubMed]

4. Masih, A.; Lall, A.S.; Taneja, A.; Singhvi, R. Inhalation exposure and related health risks of BTEX in ambient air at different microenvironments of a terai zone in north India. Atmos. Environ. 2016, 147, 55-66. [CrossRef]

5. Yang, J.; Wang, K.; Zhao, Q.; Huang, L.; Yuan, C.S.; Chen, W.H.; Yang, W.B. Underestimated public health risks caused by overestimated VOC removal in wastewater treatment processes. Environ. Sci. Process. Impacts 2014, 16, 271-279. [CrossRef] [PubMed]

6. Croute, F.; Poinsot, J.; Gaubin, Y.; Beau, B.; Simon, V.; Murat, J.C.; Soleilhavoup, J.P. Volatile organic compounds cytotoxicity and expression of HSP72, HSP90 and GRP78 stress proteins in cultured human cells. Biochim. et Biophys. Acta (BBA)-Mol. Cell Res. 2002, 1591, 147-155. [CrossRef]

7. Jia, C.; Yu, X.; Masiak, W. Blood/air distribution of volatile organic compounds (VOCs) in a nationally representative sample. Sci. Total Environ. 2012, 419, 225-232. [CrossRef]

8. Doherty, R.E. A history of the production and use of carbon tetrachloride, tetrachloroethylene, trichloroethylene and 1,1,1-trichloroethane in the United States: Part 1-historical background; carbon tetrachloride and tetrachloroethylene. Environ. Forensics 2000, 1, 69-81. [CrossRef]

9. Huang, B.; Lei, C.; Wei, C.; Zeng, G. Chlorinated volatile organic compounds (Cl-VOCs) in environment-sources, potential human health impacts, and current remediation technologies. Environ. Int. 2014, 71, 118-138. [CrossRef]

10. Beamer, P.I.; Luik, C.E.; Abrell, L.; Campos, S.; Martínez, M.E.; Sáez, A.E. Concentration of trichloroethylene in breast milk and household water from Nogales, Arizona. Environ. Sci. Technol. 2012, 46, 9055-9061. [CrossRef]

11. IARC. Summaries \& evaluations. Trichloroethylene 1995, 6, 75.

12. U.S. EPA. Toxicity and exposure assessment for children's health. Trichloroethylene-TEACH chemical summary. Available online: http://www.epa.gov/teach/chem_summ/TCE_summary.pdf (accessed on 17 December 2019).

13. Farhadian, M.; Vachelard, C.; Duchez, D.; Larroche, C. In situ bioremediation of monoaromatic pollutants in groundwater: A review. Bioresour. Technol. 2008, 99, 5296-5308. [CrossRef] [PubMed]

14. Kao, C.M.; Huang, W.Y.; Chang, L.J.; Chen, T.Y.; Chien, H.Y.; Hou, F. Application of monitored natural attenuation to remediate a petroleum-hydrocarbon spill site. Water Sci. Technol. 2006, 53, 321-328. [CrossRef] [PubMed]

15. ACGIH, T. BEIs based on the documentation of the threshold limit values for chemical substances and physical agents and biological exposure indices 2009 Cincinnati. In American Conference of Governmental Industrial Hygienists; ACGIH: Cincinnati, OH, USA, 2006.

16. Tunsaringkarn, T.; Siriwong, W.; Rungsiyothin, A.; Nopparatbundit, S. Occupational exposure of gasoline station workers to BTEX compounds in Bangkok, Thailand. Int. J. Occup. Environ. Med. 2012, 3, 117-125. [PubMed]

17. Costa, A.S.; Romão, L.P.C.; Araújo, B.R.; Lucas, S.C.O.; Maciel, S.T.A.; Wisniewski Jr, A.; Alexandre, M.D.R. Environmental strategies to remove volatile aromatic fractions (BTEX) from petroleum industry wastewater using biomass. Bioresour. Technol. 2012, 105, 31-39. [CrossRef] [PubMed]

18. Anjum, H.; Johari, K.; Gnanasundaram, N.; Ganesapillai, M.; Arunagiri, A.; Regupathi, I.; Thanabalan, M. A review on adsorptive removal of oil pollutants (BTEX) from wastewater using carbon nanotubes. J. Mol. Liq. 2018, 277, 1005-1025. [CrossRef]

19. Ali, I.; Asim, M.; Khan, T.A. Low cost adsorbents for the removal of organic pollutants from wastewater. J. Environ. Manag. 2012, 113, 170-183. [CrossRef]

20. Coin, R.J.; Niksa, M.J.; Elyanow, D.I. Wastewater treatment enhanced by electrochemistry. Environ. Prog. Sustain. Energy 1996, 15, 122-127. [CrossRef]

21. Crisafully, R.; Milhome, M.A.L.; Cavalcante, R.M.; Silveira, E.R.; De Keukeleire, D.; Nascimento, R.F. Removal of some polycyclic aromatic hydrocarbons from petrochemical wastewater using low-cost adsorbents of natural origin. Bioresour. Technol. 2008, 99, 4515-4519. [CrossRef]

22. Zinkus, G.A.; Byers, W.D.; Doerr, W.W. Identify appropriate water reclamat'technologies. Chem. Eng. Prog. 1998, 19.

23. Fierro, V.; Torné-Fernández, V.; Montané, D.; Celzard, A. Adsorption of phenol onto activated carbons having different textural and surface properties. Microporous Mesoporous Mater. 2008, 111, 276-284. [CrossRef] 
24. Mohammed, M.A.; Shitu, A.; Tadda, M.A.; Ngabura, M. Utilization of various Agricultural waste materials in the treatment of Industrial wastewater containing Heavy metals: A Review. Int. Res. J. Environ. Sci. 2014, 3, 62-71.

25. Park, K.H.; Balathanigaimani, M.S.; Shim, W.G.; Lee, J.W.; Moon, H. Adsorption characteristics of phenol on novel corn grain-based activated carbons. Microporous Mesoporous Mater. 2010, 127, 1-8. [CrossRef]

26. Yu, L.; Wang, L.; Xu, W.; Chen, L.; Fu, M.; Wu, J.; Ye, D. Adsorption of VOCs on reduced graphene oxide. J. Environ. Sci. 2018, 67, 171-178. [CrossRef]

27. Bansal, R.C.; Goyal, M. Activated Carbon Adsorption; CRC press: Boca Raton, FL, USA, 2015.

28. Derbyshire, F.; Jagtoyen, M.; Andrews, R.; Rao, A.; Martin-Gullon, I.; Grulke, E.A. Carbon Materials in Environmental Applications. In Chemistry and physics of carbon; Marcel Dekker Inc.: New York, NY, USA, 2001; pp. 1-66.

29. Zhang, X.; Gao, B.; Creamer, A.E.; Cao, C.; Li, Y. Adsorption of VOCs onto engineered carbon materials: A review. J. Hazard. Mater. 2017, 338, 102-123. [CrossRef]

30. Ahmaruzzaman, M. Adsorption of phenolic compounds on low-cost adsorbents: A review. Adv. Colloid Interface Sci. 2008, 143, 48-67. [CrossRef]

31. Baek, M.H.; Ijagbemi, C.O.; Se-Jin, O.; Kim, D.S. Removal of Malachite Green from aqueous solution using degreased coffee bean. J. Hazard. Mater. 2010, 176, 820-828. [CrossRef]

32. Crini, G. Non-conventional low-cost adsorbents for dye removal: A review. Bioresour. Technol. 2006, 97, 1061-1085. [CrossRef]

33. García-Sabido, D.; López-Mesas, M.; Carrillo-Navarrete, F. Chicken feather fibres waste as a low-cost biosorbent of acid Blue 80 dye. Desalin. Water Treat. 2016, 57, 3732-3740. [CrossRef]

34. Tan, X.; Liu, Y.; Zeng, G.; Wang, X.; Hu, X.; Gu, Y.; Yang, Z. Application of biochar for the removal of pollutants from aqueous solutions. Chemosphere 2015, 125, 70-85. [CrossRef]

35. Acharya, J.; Kumar, U.; Rafi, P.M. Removal of heavy metal ions from wastewater by chemically modified agricultural waste material as potential adsorbent-a review. Int. J. Curr. Eng. Technol. 2018, 8, 526-530. [CrossRef]

36. Agwaramgbo, L.; Lathan, N.; Edwards, S.; Nunez, S. Assessing lead removal from contaminated water using solid biomaterials: Charcoal, coffee, tea, fishbone, and caffeine. J. Environ. Prot. 2013, 4, 741. [CrossRef]

37. Aman, T.; Kazi, A.A.; Sabri, M.U.; Bano, Q. Potato peels as solid waste for the removal of heavy metal copper (II) from waste water/industrial effluent. Colloids Surf. B Biointerfaces 2008, 63, 116-121. [CrossRef]

38. Fu, F.; Wang, Q. Removal of heavy metal ions from wastewaters: A review. J. Environ. Manag. 2011, 92, 407-418. [CrossRef]

39. Lakshmipathy, R.; Sarada, N.C. Application of watermelon rind as sorbent for removal of nickel and cobalt from aqueous solution. Int. J. Miner. Process. 2013, 122, 63-65. [CrossRef]

40. Mallampati, R.; Valiyaveettil, S. Application of tomato peel as an efficient adsorbent for water purification-alternative biotechnology? Rsc. Adv. 2012, 2, 9914-9920. [CrossRef]

41. Frezzini, M.A.; Giuliano, A.; Treacy, J.; Canepari, S.; Massimi, L. Food Waste Materials Appear Efficient and Low-cost Adsorbents for the Removal of Organic and Inorganic Pollutants from Wastewater. Interface Sci. 2018, 316, 298-309. [CrossRef]

42. Massimi, L.; Giuliano, A.; Astolfi, M.L.; Congedo, R.; Masotti, A.; Canepari, S. Efficiency evaluation of food waste materials for the removal of metals and metalloids from complex multi-element solutions. Materials 2018, 11, 334. [CrossRef]

43. Vieira, R.H.; Volesky, B. Biosorption: A solution to pollution? Int. Microbiol. 2000, 3, 17-24.

44. Kargi, F.; Cikla, S. Biosorption of zinc (II) ions onto powdered waste sludge (PWS): Kinetics and isotherms. Enzym. Microb. Technol. 2006, 38, 705-710. [CrossRef]

45. Mirabella, N.; Castellani, V.; Sala, S. Current options for the valorization of food manufacturing waste: A review. J. Clean. Prod. 2014, 65, 28-41. [CrossRef]

46. Scheufele, F.B.; Módenes, A.N.; Borba, C.E.; Ribeiro, C.; Espinoza-Quiñones, F.R.; Bergamasco, R.; Pereira, N.C. Monolayer-multilayer adsorption phenomenological model: Kinetics, equilibrium and thermodynamics. Chem. Eng. J. 2016, 284, 1328-1341. [CrossRef]

47. Wang, X.S.; Qin, Y. Equilibrium sorption isotherms for of $\mathrm{Cu} 2+$ on rice bran. Process. Biochem. 2005, 40, 677-680. [CrossRef] 
48. Aly, Z.; Graulet, A.; Scales, N.; Hanley, T. Removal of aluminium from aqueous solutions using PAN-based adsorbents: Characterisation, kinetics, equilibrium and thermodynamic studies. Environ. Sci. Pollut. Res. 2014, 21, 3972-3986. [CrossRef]

49. Hamzaoui, M.; Bestani, B.; Benderdouche, N. The use of linear and nonlinear methods for adsorption isotherm optimization of basic green 4-dye onto sawdust-based activated carbon. J. Mater. Env. Sci. 2018, 9, 1110-1118. [CrossRef]

50. Ho, Y.S. Isotherms for the sorption of lead onto peat: Comparison of linear and non-linear methods. Pol. J. Environ. Stud. 2006, 15, 81-86.

51. Chen, X. Modeling of experimental adsorption isotherm data. Information 2015, 6, 14-22. [CrossRef]

52. Aly, Z.; Luca, V. Uranium extraction from aqueous solution using dried and pyrolyzed tea and coffee wastes. J. Radioanal. Nucl. Chem. 2013, 295, 889-900. [CrossRef]

53. Iqbal, M.; Saeed, A.; Zafar, S.I. FTIR spectrophotometry, kinetics and adsorption isotherms modeling, ion exchange, and EDX analysis for understanding the mechanism of $\mathrm{Cd} 2+$ and $\mathrm{Pb} 2+$ removal by mango peel waste. J. Hazard. Mater. 2009, 164, 161-171. [CrossRef]

54. Guechi, E.K.; Hamdaoui, O. Sorption of malachite green from aqueous solution by potato peel: Kinetics and equilibrium modeling using non-linear analysis method. Arab. J. Chem. 2016, 9, S416-S424. [CrossRef]

55. Pujol, D.; Liu, C.; Gominho, J.; Olivella, M.À.; Fiol, N.; Villaescusa, I.; Pereira, H. The chemical composition of exhausted coffee waste. Ind. Crop. Prod. 2013, 50, 423-429. [CrossRef]

56. Kaneko, T.; Wang, P.Y.; Sato, A. Relationship between blood/air partition coefficients of lipophilic organic solvents and blood triglyceride levels. Toxicology 2000, 143, 203-208. [CrossRef]

57. Sikkema, J.; Weber, F.J.; Heipieper, H.J.; Bont, J.A.D. Cellular toxicity of lipophilic compounds: Mechanisms, implications, and adaptations. Biocatalysis 1994, 10, 113-122. [CrossRef]

58. Largitte, L.; Pasquier, R. A review of the kinetics adsorption models and their application to the adsorption of lead by an activated carbon. Chem. Eng. Res. Des. 2016, 109, 495-504. [CrossRef]

59. Tan, K.L.; Hameed, B.H. Insight into the adsorption kinetics models for the removal of contaminants from aqueous solutions. J. Taiwan Inst. Chem. Eng. 2017, 74, 25-48. [CrossRef]

60. El-Khaiary, M.I.; Malash, G.F. Common data analysis errors in batch adsorption studies. Hydrometallurgy 2011, 105, 314-320. [CrossRef]

61. Dada, A.O.; Olalekan, A.P.; Olatunya, A.M.; Dada, O. Langmuir, Freundlich, Temkin and Dubinin-Radushkevich isotherms studies of equilibrium sorption of $\mathrm{Zn} 2+$ unto phosphoric acid modified rice husk. Iosr J. Appl. Chem. 2012, 3, 38-45.

62. Febrianto, J.; Kosasih, A.N.; Sunarso, J.; Ju, Y.H.; Indraswati, N.; Ismadji, S. Equilibrium and kinetic studies in adsorption of heavy metals using biosorbent: A summary of recent studies. J. Hazard. Mater. 2009, 162, 616-645. [CrossRef]

(C) 2019 by the authors. Licensee MDPI, Basel, Switzerland. This article is an open access article distributed under the terms and conditions of the Creative Commons Attribution (CC BY) license (http://creativecommons.org/licenses/by/4.0/). 